\title{
Lexical Cohesion of Antonyms in The Folklore Literature Materials Titled Asal-Usul Burung Hantu
}

\author{
Ina Nurannisa ${ }^{1}$, Agustina $^{2}$, and Ngusman Abdul Manaf ${ }^{3}$ \\ \{inanurannisa@student.unp.ac.id ${ }^{1}$, ngusman@fbs.unp.ac.id ${ }^{2}$ \} \\ ${ }^{1,2,3}$ Language and Arts Faculty, Padang State University, Padang, 71500, Sumatera Barat, Indonesia.
}

\begin{abstract}
The folklore literature titled Asal-Usul Burung Hantu was published by the Language Development and Fostering Agency in 2016. This one of the recommended folklore books as supporters of the National Literacy Movement, and is most widely downloaded from the page gln.kemdikbud.go.id. This research aims to describe discourse cohesive supported by aspects of the lexical cohesion, especially the antonyms. This is qualitative research. The source of data used is Asal-Usul Burung Hantu folklore discourse. Techniques of collecting data in this research are the library method, view, and record methods. Based on the analysis, there are two findings, namely (1)there are six variations of antonym, (2)there are five forms of antonym.
\end{abstract}

Keywords: lexical cohesion, antonymy, literacy, and the Asal-Usul Burung Hantu folklore

\section{Introduction}

Literacy material for folklore entitled Asal-Usul Burung Hantu [1] published by the Language Development and Fostering Agency is one of the recommended folklore books as supporters of the National Literacy Movement and is most widely downloaded from the page gln.kemdikbud.go.id. This folklore is used as a means of supporting the literacy movement to facilitate student access to reading books to get reading material easily. This written discourse certainly cann't be separated from one unit of meaning.

One of the interesting words meaning relations to study is the meaning relationship which states the contradiction or antonym. Many times someone interprets that anonymity is the opposite of words. Actually, antonyms are contradictions/conflicts of meaning. The antonymic lexical cohesion doesn't play a role as a synonym for the role of synonymy because antonymy consists of pairs of words, the nature of each of these words plays an important role in presenting a unity of meaning.

Antonymy has the meaning of opposition meaning in lexical pairs that can be stretched, for example high: low (not "high" doesn't mean "low") [2]. Furthermore, antonyms are several pairs of words that have opposite meanings [3]. Next opinion, antonym is a semantic relationship between two words whose meaning stating the opposite, opposition, or the contrast between one another and the relationship of the two words is two-way [4]. Antonyms are expressions (usually words, but can also be phrases or sentences) that are considered to mean the opposite of other expressions. It can be simply concluded that antonyms are words whose meanings are the opposite. For example, a good word is the opposite of a bad word; and the buy word is the opposite of the sell word [5]. Antonymy (opposite word) is a part of lexical cohesion that is related to other names for objects or other things; or lingual units 
whose meanings are opposite/in opposition to other lingual units [6]. Antonymy is also called the opposition of meaning which includes concepts that are opposite to those which only contrast meaning. By its nature, antonymy is divided into absolute opposition, polar opposition, relations opposition, hierarchical opposition, and plural opposition.

Antonyms in the morpheme level occur because of differences in phonemes found in pairs of words, for example progressive opposing meanings with regressive [7]. Antonymy or the opposite of words is one form of lexical cohesion which is interpreted as another name for objects/other things, or lingual units whose meanings are opposite/in opposition to other lingual units. Antonyms aren't only at the word level, but antonyms are also at the morpheme level, phrase level, and sentence level [8]. Therefore antonymy is also called opposition of meaning, which includes concepts that are opposite to those that only contrast meaning. By their very nature, the opposition of meaning can be divided into five, namely absolute opposition, polar opposition, relations opposition, hierarchical opposition, and plural opositions.

A number of studies using lexical cohesion devices, especially antonyms, have been conducted by Chunming Gao and Qianzhen Zheng about a linguistic study of antonymy in English Texts [9]; Josephine B. Alarcon about the lexical cohesion in students' argumentative essay among a select group of Filipino College Students [10]; Siti Nor Fatimah Haris and Melor Md Yunus about the use of lexical cohesion among TESL post graduate students in academic writing [11]; Dilin Liu about the writing cohesion: using content lexical ties in ESOL [12]; Jian-Sheng Yang about a contrastive study of cohesion in English and Chinese [13]; Carita Paradis and Caroline Willners about the Selecting antonyms for dictionary entries: methodological aspects [14]; Caroline Willners about the antonyms in context a corpus-based semantic analysis of Swedish descriptive adjectives [15].; M. Lynne Murphy, Carita Paradis, Caroline Willners, and Steven Jones about the discourse functions of antonymy: a crosslinguistic investigation of Swedish and English [16]; and Carita Paradis, Caroline Willners, and Steven Jones about the Good and bad opposites: Using textual and experimental techniques to measure antonym canonicity [17].

After research by examining the text, the literacy material of folklore Asal-Usul Burung Hantu published by the Language Development and Foresting Agency enables the emergence of anthemic lexical cohesion, because the cohesion of antonymic cyclical arising that appears in the text will support the formation of discourse cohesion in a single discourse. Besides, the meaning that is raised will be fully exposed. Therefore, researchers examined "Antonymy's Lexical Cohesion in literary material folklore Asal-Usul Burung Hantu published by the Language Development and Foresting Agency". In this study, researchers sought to explain variations in shape, type of antonym, and the precise use of antonym lexical cohesion.

\section{Methods}

The data source of this research is the literacy material of the folklore Asal-Usul Burung Hantu published by the 2016 Language Development and Foresting Agency which is one of the recommended folklore books as supporters of the National Literacy Movement, downloaded from the page gln.kemdikbud.go.id. The data in this study are the intercultural relationship.

This research was conducted in three stages of the method, namely (1) data collection techniques, (2) data analysis techniques, and (3) data analysis results presentation techniques. The data source of this research is written data. In the text discourse literary material folklore Asal-Usul Burung Hantu published by the Agency for Development and Language 
Development, especially words and language that shows the existence of conflicting meanings (antonymy). From the use of grammatical and lexical cohesion aspects. Collecting data in this study using library techniques, refer to, and record.

\section{Results and Discussion}

Found 75 data that show antonyma lexical cohesion in the Asal-Usul Burung Hantu folklore.

\subsection{Variations in the Forms of Antonymy's Lexical Cohesion}

Antonymic lexical cohesion contained in literary material folklore Asal-Usul Burung Hantu there are several forms of variation, namely antonyms between words with words, word antonyms with phrases, antonyms for phrases and phrases, antonyms for clauses with clauses, antonyms for clauses and sentences, and antonyms for sentences with sentences.

\subsubsection{Antonymy between words with words}

Antonymy between word and word is antonym that shows the relationship of conflicting meaning between word and word.

(1) "Ibu harap kelak engkau dapat mencari kehidupan yang bahagia carilah pasangan hidup yang bisa menjagamu!” ujar sang ibu dengan suara yang parau akibat sakit yang dideritanya.Setelah mendengar ucapan sang ibu tercinta, Dayu merasa sangat sedih.(SK10/2-SK11/1)

("I hope that someday you can find a happy life looking for a life partner who can take care of you!" Said the mother in a raspy voice due to her pain. After hearing the words of his beloved mother, Dayu felt very sad.)

(2) Sang ibu yang telah tua dan sakit-sakitan merasa kasihan terhadap anaknya yang sehari-hari hanya disibukkan mengurus dirinya. (SK1/5)

(The elderly and sickly mother feels sorry for her child, who is only busy taking care of herself everyday.)

(3) Tidak lama kemudian, datanglah ketiga pria kekar yang kemarin dan menagih janji mereka kepada perempuan tua itu. Tak lama berselang, terlihat para penagih utang itu pergi dengan membawa banyak hasil panen milik perempuan tua.(PT12/1-2)

(Not long after, there came three burly men were yesterday and collect their promise to the old woman. Not long ago, it was seen that the debt collectors left, bringing with them many of the harvest results of the old woman.)

In the quote (1) above, happy $><$ sad is an adjective form of words, both of which express nature. Happiness means a state or feeling of pleasure and peace (free from all that is troublesome). Sad means feeling very sad in the heart. Antonymy (2) mother $><$ her child is a form of pronouns/nouns, her child has a basic form of child. Antonym (3) come $><$ go is a verb/verb form. Come get an affix (-lah) so that the word states the action/action, and has a basic form to come. Come means to be present or appear. To go means to leave (somewhere).

\subsubsection{Antonymy between words and phrases}

Antonymics between words and phrases are antonym that show the relationship of conflicting meaning between words and phrases.

(4) Ketika kembali, Burung Hantu melihat adiknya telah tidur lelap. Burung itu pun tak tega untuk membangunkan sang adik. (PT37/4) 
(When he returns, the owl sees his little brother sleeping soundly. The bird did not have the heart to wake the younger sibling.)

(5) Burung Hantu kembali ke hutan yang tidak jauh dari ladang. Burung itu kemudian bertengger di pohon yang cukup besar. Tak lama kemudian seekor tikus mendekat. (BT1/1-2)

(The owl returns to the forest not far from the field. The bird then perches on a large tree. Shortly thereafter a mouse approaches.)

(6) Sang ibu menyambut anak tercintanya. (BKDI17/5)

(The mother welcomes her beloved child.)

In quote (4) there is deep sleep $><$ awaken. Both words include verbs. Deep sleep is a form of verb phrase because it consists of two words (occupying a function) which states a verb/verb and awakens is a form of a word. Antonym (5)not far $><$ close is a verb/verb form. Not far away is a verb form because it consists of two words (occupying a function) which states verbs/verbs and approaches are word forms. Antonym (6)The mother $><$ child is a form of pronoun person/pronoun. The mother is a form of noun phrases because it consists of two words (occupying a function) which states the pronouns/nouns and the child is the form of the pronouns/noun.

\subsubsection{Antonymics between phrases and phrases}

Antonymics between phrases and phrases are antonym that show the relationship between the meaning of the phrase with the phrase.

(7) Sang Ibu pun bekerja keras untuk menghidupi kedua anaknya. (KD7/1

(The mother works hard to support her two children.)

(8) Jadi, biarkan saja taruhan ini kita lanjutkan dengan berharap ada keajaiban datang pada kita. Jika tidak ada keajaiban, bersiaplah kita semua meninggalkan kampung ini mencari tempat yang lebih baik untuk kita tinggali dan kita mulai semuanya dari awal. (TP11/5-6)

(So, let's just let this bet continue by hoping that a miracle will come to us. If there is no miracle, prepare us all to leave this village in search of a better place for us to live in and we will start everything from the beginning.)

(9) Semua panen milik Pak Kosih telah selesai dihitung, para juru hitung mulai menghitung hasil panen milik warga kampung. (TP19/1)

(All harvests belonging to Mr. Kosih have been counted, the counters have begun to count the yields belonging to the villagers.)

In the quote (7) above, there is a conflict of meaning between the mother and her two children. The two phrases are pronouns because they consist of more than two words occupying a function.In the phrase 'the mother' the word 'mother' is the core word, and in the phrase 'the two children' the word 'child' is a core word. Antonym (8) there is a miracle $><$ there is no miracle is a noun phrase because it consists of more than two words occupying a function. The two phrases that show nouns are words of miracle. The word miracle in both phrases is the core word. Antonym (9) has finished counting $><$ start counting is a verb phrase because it consists of more than two words occupying a function. The two phrases that indicate verbs are arithmetic words. The word count in both phrases is the core word. 


\subsubsection{Antonymy between clause and clause}

Antonymy between clause and clause is antonym that shows the relationship between the clash of meaning between clause and clause.

(10) Pak Kosih dan Bu Kosih terlihat tersenyum penuh kemenangan karena keyakinan mereka yang sudah pasti menang. Sementara itu, wajah-wajah para warga kampung terlihat cemas menunggu hasil hitungan juru hitung. (TP18/4-5) (Mr. Kosih and Mrs. Kosih are seen smiling triumphantly because of their certainty of winning. Meanwhile, the faces of the villagers looked anxiously waiting for the counters to count.)

In the quote (10) above, Mr. Kosih and Mrs. Kosih are seen smiling triumphantl $><$ The villagers are worried that they are antimony between clause and clause. The first clause (Mr. Kosih and Mrs. Kosih is seen smiling triumphantly ) patterned subject-predicate (SP). Mr. Kosih and Mrs. Kosih as subjects, and seen smiling triumphantly as a predicate. The second clause (the villagers look worried) patterned subject-predicate (SP). Villagers as subjects, and look worried as a predicate.

\subsubsection{Antonymy between clauses and sentences}

Antonymics between clauses and sentences are antonymes which show the relationship between the clash of meanings and sentences.

(11) Kami akan menjaga padi ini dengan baik," jawab Dara Ranti dengan senang hati. Namun, sebaliknya Bujang Ampan yang pura-pura tidak mendengar perintah ibunya. (KD10/2-3)

(We will take good care of this rice, "answered Dara Ranti happily. However, on the contrary Bujang Ampan who pretended not to hear his mother's orders.)

In the quote (11) above, we will take good care of this rice $><$ Bujang Ampan who pretends not to hear his mother's orders are antimony between clauses and sentences. Antonymy in this data clause We will keep this rice well consisting of subject sentence patterns, predicates, objects, and way information (SPOK). Meanwhile, Bujang Ampan who pretended not to hear his mother's orders was in the form of a sentence. The series of words can be referred to as a sentence because it qualifies as a sentence, beginning with a capital letter and ending with a dot, and patterned subject-predicate-object (SPO).

\subsubsection{Antonymy between sentences by sentences}

Antonymics between sentences and sentences are antonyms that show the relationship between the meaning of the sentence and the sentence.

(12) Jika kautebarkan pada benda apa pun asalkan milik orang yang berhati baik, serbuk surga ini akan menghasilkan sesuatu keajaiban yang indah. Namun sebaliknya, jika kautebar pada benda apa pun milik orang yang berhati busuk, serbuk surga ini akan berdampak buruk baginya.(SN13/4-5)

(If you spread it on any object as long as it belongs to a person with a good heart, this heavenly powder will produce a beautiful miracle. But on the contrary, if you spread on anything that belongs to a person with a bad heart, this heavenly powder will have a bad effect on him.) 
The antonymy of data (12) is antimatallic antonym. Both sentence qualify as sentences. (a) Both are preceded by a capital letter. (b) The sentence ends with a period. (c)Sentence 1 is complementary-subject-predicate-object pattern (Pel.-SP-Ket. Outcome), as well as sentence 2 with complementary- subject- predicate- object- pattern (Pel.- SP- Ket. Outcome).

\subsection{Types of Antonymy's Lexical Cohesion}

Antonymy can be interpreted as another name for an object or something else; or lingual units whose meanings are opposite/in opposition to other lingual units. Antonymy also called opposition meaning. The notion of oppositional meaning encompasses concepts that are completely opposite to those of contrasting meanings. In the literary material of folklore AsalUsul Burung Hantu there are five types of antonym lexical cohesion. The five types of opposition meaning are absolute opposition, polar, relationship, hierarchical, and compound.

\subsubsection{Absolute Opposition}

Absolute antithmetic occurs because of a conflict between two words that contradict their meaning absolutely.This opposition is "yes" or "no" meaning that if one applies then the other does not apply. That is, the contradiction of meaning is a conflict between words/ phrases/clauses/sentences with words/phrases/clauses/sentences that have full, complete, and unlimited conflict, and the contradiction cannot be denied.

(13) Setelah kematian ayahnya, kehidupan mereka menjadi semakin susah. (KDl/3) (Having to die late father, to live an they are becoming increasingly difficult.)

(14) Oleh sebab itu, kita tidak mungkin memenangkan taruhan ini. Sementara itu, jika kalah, tetap saja kita akan terus tertindas dengan keadaan seperti ini. (TP11/3-4) (Therefore, we may not be me to win right bet. Meanwhile, if we lose, we will continue to be oppressed under these circumstances.)

In the quote above, there is absolute opposition (13) between right and wrong; if not true means wrong, if not wrong means right. Antonyms (14) between win and lose; if not winning means losing, if not losing means winning. Everything has absolutely contradictory meanings.

\subsubsection{Polar Antonymy}

Polar Antonymy is an opposition of meaning which is not absolute, but gradual. That is, there are levels of meaning in these words. This polar opposition occurs because of the level of meaning of words marked by the use of words rather and very.

(15) Engkau cekatan dalam bekerja seperti ayahmu dulu. Walaupun adikmu malas bekerja, ibu tetap sayang terhadap kalian berdua," ujar ibu sambil menikmati jagung yang disediakan Dara Ranti. (KD4/3-4)

(You are as skillful at work as your father was. Even though your sister is lazy to work, I still love you both,"said the mother while enjoying the corn provided by Dara Ranti.)

(16) Oh Ibu, sungguh berat bebanmu yang engkau tanggung selama ini. Wajarlah jika engkau begitu marah kepada diriku. Padahal, tugasku sungguhlah ringan hanya menjaga jemuran padi, tetapi aku tidak bisa melakukannya dengan baik. (PT2/35) 
(Oh Mother, what a burden you have endured so far. Naturally, if you are so angry with me. In fact, my job is really light just to keep the rice drying, but I can't do it well.)

(17) Diambilnya sedikit serbuk surga itu dan mulai ia tebarkan di hasil panen milik warga. Setelah itu, Burung Hantu terbang menuju tempat Pak Kosih dan menebarkan bubuk surga di hasil panen milik Pak Kosih yang melimpah. (TP17/2-3)

(He took a little of the heavenly powder and began to scatter it on the crops of the people. After that, the Owl flies to Mr. Kosih's place and spreads heaven's powder on Mr. Kosih's abundant harvest.)

In the example of the quote, there is a polar opposition (15) between work man like and lazy to work; (16) between weight and light; and (17) between a few with abundance. It is not known what is called 'deft in work' is the size of how it can be "very dexterous" $><$ "very lazy", "rather deftly"><"somewhat lazy", or can also be "quite dexterous" >< "very lazy". Likewise in the example of quote (16), it is not known what is called "weight" in terms of size, as well as lightly. It could be said to be "very heavy" $><$ "very light", "rather heavy" $><$ "rather light", "rather heavy"><"very light". Beg also in the example quote (17), it is unknown what is called "a little" the size of how much, maybe it can be "very little" $><$ "very abundant", or "quite a bit" $><$ "somewhat abundant", or it could be "very little" $><$ "rather abundant". All of them have conflicting meanings, but they are gradations or levels.

\subsubsection{Antonymy Relationship}

The antithesis of relations is the opposition of complementary meanings. So that one word may be present because of the presence of another word which is the opposition; or the presence of one word is caused by the presence of another word. The opposition of this relationship occurs when the opposing meaning of the word is complementary to one another.

(18) Mendengar jawaban sang anak tercinta sang ibu pun menangis terharu. (SK6/1) (Hearing the answer of the beloved child the mother cried with tears.)

(19) Kondisi sang ayah Apu semakin lama semakin memburuk. Sang ibu pun lebih banyak di rumah guna mengurus suami tercinta. (KAl/1-2)

(Father Apu's condition is getting worse and worse. The mother was more at home to take care of her beloved husband.)

(20) Sang suami berpostur tinggi dengan raut muka yang tampak tegang. Sementara itu, sang istri tampak mengenakan pakaian yang cukup bagus jika dinilai untuk seorang petani biasa. (TP2/2-3).

(The husband has a high posture with a tense look on his face. Meanwhile, his wife appeared to be wearing pretty good clothes if judged to be an ordinary farmer.)

In this quote, there is an opposing relationship (18) between the child's lingual unit and the mother's lingual unit in the same sentence. Children exist because their presence is complemented by their mother. Likewise with mothers, their presence will be meaningful if equipped with children. In the citation (19) between the unit lingual father with units lingual the mother on the line next. Father as a reality is possible because his presence is complemented by his mother and vice versa. In quote (20) between the husband's lingual unit and the wife's lingual unit in a different sentence. Husband as a reality is possible because of his presence complemented by his wife and vice versa. 


\subsubsection{Antonymy Hirarkial}

Hierarchical anthropology is antimony of meaning which states a series of levels or levels. Lingual units which are hierarchical in general are words that refer to the names of the units of measure.

(21) Hari berganti hari, bulan berganti bulan tanpa terasa kedua anak itu beranjak menjadi remaja yang cantik dan tampan. (BB4/1)

(month after month without the two children felt to be a beautiful and handsome teenager.)

(22) Hari berganti hari, bulan berganti bulan tanpa terasa kedua anak itu beranjak menjadi remaja yang cantik dan tampan. (BB4/1)

(Day after day, month after month without the two children felt to be a beautiful and handsome teenager.)

(23) Mereka pergi pagi dan pulang petang. (BB2/5)

(They leave early in the morning and return later in the evening.)

In these quotations found the unit lingual support discourse cohesion lexical and semantic, ie (21) there is a hierarchical opposition day by day and month turned into months that depict levels of time from a matter of days to a matter of months. In quote (22) there is a hierarchical opposition between the two children and the teenager who describes the process of one's growth from child to teenager. In quote (23)there is a hierarchical opposition morning, afternoon, evening, and night that illustrates the reality of the level of time, ie between the unit of morning time that is positioned and the morning which is positioned with the evening.

\subsubsection{Compound Antonymy}

Compound Antonymy is the opposition of meaning that occurs in several words (more than one). The following data illustrates compound antonym.

(24) "Ibu, apa yang Ibu katakan? Ibu tidak boleh meninggalkan Dayu, Bu. Dayu sayang Ibu." Dayu mencurahkan rasa sedihnya setelah mendengar perkataan ibunya. (SK12/1-3-SK13/1)

("Mother, what did you say? You can't leave Dayu, ma'am. Dayu dear mother." Dayu poured out her sadness after hearing her mother's words.)

(25) Tidak lama kemudian, Dayu pun mengandung. Ia melahirkan seorang anak perempuan. (BB3/1-2)

(Not long after, Dayu was pregnant . He gave birth to a daughter.)

(26) Ia malah pergi bermain ke sungai. Padi dan jagung yang sedang dijemur tersebut ditinggalkannya. Karena padi dan jagung tersebut tidak ada yang menjaga, berdatanganlah ayam dan burung untuk memakan padi dan jagung-jagung yang sedang dijemur itu. (KD15/2-3)

(Instead he went to play in the river. He left the rice and corn being dried in the sun. Because the rice and corn unattended, berdatanganlah chickens and birds to eat rice and corn-corn being dried it.)

In these quotations found the unit lingual support discourse cohesion lexical semantic, ie in (24) are o position of hierarchical say and hear, the unit lingual it describes a person who is saying something and no other party is listening. In quotation (25) there is an opposition to the hierarchy al containing and giving birth, in the lingual unit it describes a person who is pregnant until later he gives birth. In quote (26) the word goes in the above quotation can be in opposition to the word abandonment and come. 


\section{Conclusion}

Based on the results of the research and discussion, it was concluded that the results of the study by applying Halliday's theory [18] to the type of lexical cohesion of antonymy type in literary material folklore Asal-Usul Burung Hantu published by the Language Development and Fostering Agency there are markers of antonym lexical cohesion so that there is cohesive discourse.

Based on the analysis, there are some kinds of variations, namely antonymy between word by word, antonymy between words with phrases, antonymy between phrases with phrases, antonymy between clause by clause, antonymy between clause with sentences, and antonymy between sentences by sentences. Besides, the antonymy aspects are found, namely absolute antonym, polar antonym, antonym of relationship, hierarchical antonym, and compound antonym. The most striking aspect of this antonym aspect lies in the semantic lexical cohesion of discourse that describes the lingual unit and hierarchical opposition of a discourse.

\section{Acknowledgments.}

We would like to thank the anonymous reviewers for their useful suggestions and recommendations on the earlier version of this paper. We thank our educational institution, Padang State University, for providing insights and expertise that have greatly helped research, even though this paper isn't perfect.

\section{References}

[1] Duantika, P. (2016). Asal-Usul Burung Hantu: Cerita Rakyat dari Kalimantan Barat. Jakarta: Badan Pengembangan dan Pembinaan Bahasa.

[2] Hasan Alwi (pimred) Kepala Pusat Bahasa. (2003). Kamus Besar Bahasa Indonesia (KBBI). Kementerian Pendidikan dan Budaya.

[3] Alwasilah, C. (2011). Linguistik Suatu Pengantar. Bandung: Angkasa.

[4] Chaer, A. (2012). Linguistik Umum. Jakarta: Rineka Cipta.

[5] Verhaar, J.W.M. (2012). Asas-Asas Linguistik Umum. Yogyakarta: Gadjah MadaUniversity Press.

[6] Sumarlam. Ed. (2010). Teori dan Praktik Analisis Wacana. Surakarta: Pustaka Cakra.

[7] Mulyana. (2005). Kajian Wacana. Teori, Metode, dan Aplikasi Prinsip-Prinsip Analisis Wacana. Yogyakarta: Tiara Wacana.

[8] Suwandi, S. (2011). Semantik Pengantar Kajian Makna. Yogyakarta: Media Perkasa.

[9] Zheng, Q., \& Gao, C. (2014). A linguistic study of antonymy in english texts. Journal of Language Teaching and Research, 5(1), 234-238. https://doi.org/10.4304/j1tr.5.1.234-238

[10] Alarcon, J. B. (2013). Research Papers Lexical Cohesion In Students ' Argumentative Essay By. 3(2), 43-52.

[11] Fatimah, S. N., Haris, \&Yunus, M. M. (2014). The Use of Lexical Cohesion among TESL Post Graduate Students. Journal of Education and Human Development, 3(2), 847-869.

[12] Liu, B. D. (1997). Writing Cohesion : Using Content Lexical Ties in ESOL. (January), 206-210.

[13] Yang, J.-S. (2014). A Contrastive Study of Cohesion in English and Chinese. International Journal of English Linguistics, 4(6), 118-123. https://doi.org/10.5539/ijel.v4n6p118 
[14] Paradis, C., \& Willners, C. (2006). Selecting antonyms for dictionary entries: methodological.

[15] Willners, C. (2001). Antonyms in Context. A corpus-based semantic analysis of Swedish descriptive adjectives.

[16] Murphy, M. L., Paradis, C., Willners, C., \& Jones, S. (2009). Discourse functions of antonymy: A cross-linguistic investigation of Swedish and English. Journal of Pragmatics, 41(11), 2159-2184. https://doi.org/10.1016/j.pragma.2008.09.040

[17] Paradis, C., Willners, C., \& Jones, S. (2009). Good and bad opposites: Using textual and experimental techniques to measure antonym canonicity. The Mental Lexicon, 4(3), 380-429. https://doi.org/10.1075/ml.4.3.04par

[18] Halliday, M. A. K., \& Hasan, K. (2014). Cohesion in English. In Cohesion in English. https://doi.org/10.4324/9781315836010

[19] Arikunto, S. (2010). Manajemen Penelitian. Jakarta: Rineka Cipta.

[20] Baryadi, P. (2002). Dasar-dasar Analisis Wacana dalam Ilmu Bahasa. Cetakan Pertama. Jogjakarta: Pustaka Gondho Suli.

[21] Bunanta, M. (1998). Problematika Penulisan Cerita Rakyat. Jakarta : Balai Pustaka.

[22] Moleong, L. J. (2007). Metodologi Penelitian Kualitatif. Edisi Revisi. Bandung: Remaja Rosda Karya.

[23] Sudaryanto. (1993). Metode dan Aneka Teknik Analisis Bahasa. Yogyakarta: Duta Wacana University Press. 